\title{
Resignment: Infection is grateful to Prof. Alexander von Graevenitz
}

\author{
Johannes R. Bogner ${ }^{1}$ \\ Published online: 11 October 2018 \\ c) Springer-Verlag GmbH Germany, part of Springer Nature 2018
}

This year is the last year Professor von Graevenitz did peer reviews for Infection. This has a simple reason: aged 86 , he has decided to sign out as an active reviewer and I take the opportunity to express our gratitude to him also on behalf of my predecessors Prof. Walter Marget (+2013) and Prof. Christian Ruef.

Prof. von Graevenitz has served within the Editorial Board of Infection since 1973, and the number of his peer reviews exceeds 1000 -exactly 499 since his registration with the online peer-review system in September 2005. Moreover, he was active as an author of 25 contributions since 1984, including review articles, editorials and originals. However, perhaps equally important contributions to Infection were his support, his advice to the editors, authors, and publishers, his commitment and his friendship.

Von Graevenitz was born in 1932 in the German city of Leipzig and his present citizenship is Swiss and US-American. He lives in Switzerland where he became Director of the Department of Microbiology at the University of Zürich after a long international scientific career. After finishing medical school in 1955 in Bonn he served as a research fellow and intern/physician at many places: Bonn, Hamburg, Milwaukee, Mainz, Yale, and New Haven. During his professional life, he always was both: researcher and physician. Thus, he always was interested in research and contributions that really count for the patient. Since the year 2000, he is Professor Emeritus but ever since he remained active in many fields. Needless to mention that his curriculum is full of diplomas, awards and committee memberships. His bibliography comprises 181 originals, 66 reviews, 71 book chapters, 6 books (Editor or Co-Editor) and 37 other publications.

Johannes R. Bogner

Johannes.Bogner@med.uni-muenchen.de

1 Sektion Klinische Infektiologie, Klinik und Poliklinik IV, Klinikum der Universität München, Pettenkoferstr. 8a, 80336 Munich, Germany
Dear Professor von Graevenitz! Thank you so much for all you have done for Infection. Farewell and enjoy just reading Infection for many upcoming years.

Munich, September 2018 Johannes R. Bogner [1-25].

\section{Compliance with ethical standards}

Conflict of interest The author(s) declare that they have no competing interests.

\section{References}

1. von Graevenitz A, Carrington GO. Halophilic vibrios from extraintestinal lesions in man. Infection. 1973;1:54-8.

2. Horvitz RA, von Graevenitz A. Interpretation of blood cultures yielding Staphylococcus aureus. Infection. 1977;5:207-10.

3. Wells LD, von Graevenitz A. Clinical significance of enterococci in blood cultures from adult patients. Infection. 1980;8:147-51.

4. von Graevenitz A, Bucher C. The effect of $N$-formimidoyl thienamycin, ceftazidime, cefotiam, ceftriaxone and cefotaxime on nonfermentative Gram-negative rods, Aeromonas, Plesiomonas and Enterobacter agglomerans. Infection. 1982;10:293-8.

5. von Graevenitz A, Lennette EH. The incidence of Chlamydia psittaci antibodies in patients with respiratory tract diseases. Infection. 1982;10:240.

6. Wehrli R, von Graevenitz A, Luthy R. Susceptibility and tolerance of beta-lactamase-producing, methicillin-sensitive strains of Staphylococcus aureus towards seven broad-spectrum penicillins. Infection. 1983;11:322-5.

7. von Graevenitz A, Hany A, Wertheimer Y, Wust J, Zwicky P. Yersinia pseudotuberculosis: unusual features of a case. Infection. 1983;11:208-9.

8. von Graevenitz A. Coagulase-negative staphylococci in wounds: pathogens or contaminants? Infection. 1985;13:2-3.

9. Hachler H, Vogt K, Binswanger U, von Graevenitz A. Centrifugation of $50 \mathrm{ml}$ of peritoneal fluid is sufficient for microbiological examination in continuous ambulatory peritoneal dialysis (CAPD) patients with peritonitis. Infection. 1986;14:102-4.

10. Muller F, von Graevenitz A, Ferber T. Streptococcus milleri subcutaneous abscesses in drug addicts. Infection. 1987;15:201. 
11. Nadal D, Schwobel M, von Graevenitz A. Corynebacterium group D2 and urolithiasis in a boy with megacalycosis. Infection. 1988;16:245-7.

12. Hohl P, von Graevenitz A, Zollinger-Iten J. Cefetamet pivoxil: bacteriostatic and bactericidal activity of the free acid against 355 gram-negative rods. Infection. 1988;16:194-8.

13. von Graevenitz A, Colla F. Thyroiditis due to Brucella melitensis-report of two cases. Infection. 1990;18:179-80.

14. Huebner J, Czerwenka W, Gruner E, von Graevenitz A. Shigellemia in AIDS patients: case report and review of the literature. Infection. 1993;21:122-4.

15. Wust J, von Graevenitz A. Comparison of BacT/Alert blood culture bottles with lytic media for culture of peritoneal dialysis fluid. Infection. 1995;23:378-9.

16. Funke G, von Graevenitz A. Infections due to Actinomyces neuii (former "CDC coryneform group 1" bacteria). Infection 1995;23:73-75.

17. von Graevenitz A, Frommelt L, Punter-Streit V, Funke G. Diversity of coryneforms found in infections following prosthetic joint insertion and open fractures. Infection. 1998;26:36-8.
18. Zbinden R, Santanam P, Hunziker L, Leuzinger B, von Graevenitz A. Endocarditis due to Aerococcus urinae: diagnostic tests, fatty acid composition and killing kinetics. Infection. 1999;27:122-4.

19. Rordorf T, Zuger C, Zbinden R, von Graevenitz A, Pirovino M. Streptobacillus moniliformis endocarditis in an HIV-positive patient. Infection. 2000;28:393-4.

20. Maeder M, Vogt PR, Schaer G, von Graevenitz A, Gunthard HF. Aortic homograft endocarditis caused by Rhodotorula mucilaginosa. Infection. 2003;31:181-3.

21. von Graevenitz A. The role of Aeromonas in diarrhea: a review. Infection. 2007;35:59-64.

22. von Graevenitz A. Actinomyces neuii: review of an unusual infectious agent. Infection. 2011;39:97-100.

23. von Graevenitz A, Funke G. Turicella otitidis and Corynebacterium auris: 20 years on. Infection. 2014;42:1-4.

24. von Graevenitz A. Klebsiella pneumoniae in a patient with hoarseness and dysphagia rather than pharyngitis. Infection. 2015;43:377.

25. von Graevenitz A. In memoriam: Hans Gerd Schiefer (19352014). Infection 2015;43:131. 